\section{Inhibition of Cholesteryl Ester Transfer Protein by Fungal Metabolites, L681,512}

\author{
Noriko Tabata, Hiroshi Tomoda, Yuichi Yamaguchi, \\ RoKuro Masuma, MARK J. BAMBERGER ${ }^{\dagger}$ \\ and SATOSHI ŌMURA*
}

Research Center for Biological Function, The Kitasato Institute and Graduate School of Pharmaceutical Sciences, Kitasato University,

Minato-ku, Tokyo 108-8642, Japan

† Pfizer Inc.,

East Point Road, Connecticut 06340, USA

(Received for publication August 4, 1999)

The cholesteryl ester transfer protein (CETP) promotes exchange and transfer of neutral lipids such as cholesteryl ester (CE) and triacylglycerol (TG) between plasma lipoproteins. Evidence is accumulating for involvement of CETP in atherosclerosis ${ }^{1,2)}$. Therefore, CETP is expected as a novel target of inhibition for anti-atherosclerotic agents.

In the course of our screening for CETP inhibitors of microbial origin $^{3 \sim 7)}$, four active compounds were isolated from the culture broth of a fungal Fusarium sp. FO-6651. Based on its physico-chemical properties and NMR data, they were identified with L681,512 compounds $^{8,9}$, which were previously reported as elastase inhibitors. In this paper, the fermentation, isolation and in vitro CETP inhibitory activity of L681,512 compounds are described. Furthermore, we show that L681,512-1 proves effective in the ex vivo assay using human CETP and apo A-I transgenic mice.

\section{Characteristics of the Producing Strain}

The fungal strain FO-6651 was isolated from a soil sample collected at Nikko, Tochigi, Japan. This strain grew well on potato dextrose agar, corn meal agar, malt extract agar, Czapek yeast extract agar and Miura's medium for 4 days at $25^{\circ} \mathrm{C}$ to form colonies with diameters of $40 \sim$ $60 \mathrm{~mm}$. The colony surface was floccose to felty with a color of white. The reverse color of the colonies was white to yellowish brown. The growth was nil for 14 days at $5^{\circ} \mathrm{C}$ and $37^{\circ} \mathrm{C}$. No teleomorph was observed. Macroconidia having 1 to 3 transverse septa were hyaline in color, slightly curved in shape and $13 \sim 40 \times 3.5 \sim 5.5 \mu \mathrm{m}$ in size. From these morphological characteristics, the strain FO-6651 was considered to belong to the genus Fusarium.

\section{Fermentation}

A slant culture of the strain FO-6651 grown on YpSs agar was used to inoculate a $50-\mathrm{ml}$ test tube containing $10 \mathrm{ml}$ of a seed medium (glucose $2.0 \%$, yeast extract $0.2 \%$, $\mathrm{MgSO}_{4} \cdot 7 \mathrm{H}_{2} \mathrm{O} 0.05 \%$, Polypepton (Nippon Seiyaku) $0.5 \%$, $\mathrm{KH}_{2} \mathrm{PO}_{4} 0.1 \%$ and agar $0.1 \%$, pH 6.0 ). The tube was shaken on a reciprocal shaker for 4 days at $27^{\circ} \mathrm{C}$. Two milliliters of the seed culture was transferred into $200 \mathrm{ml}$ of the production medium (sucrose $2.0 \%$, glucose $1.0 \%$, corn steep liquor $1.0 \%$, meat extract $0.5 \%, \mathrm{KH}_{2} \mathrm{PO}_{4} 0.1 \%$, $\mathrm{MgSO}_{4} \cdot 7 \mathrm{H}_{2} \mathrm{O} 0.05 \%$, trace elements containing in $\mathrm{g} /$ liter: $\mathrm{FeSO}_{4} \cdot 7 \mathrm{H}_{2} \mathrm{O} \quad 1.0, \mathrm{MnCl}_{2} \cdot 4 \mathrm{H}_{2} \mathrm{O} \quad 1.0, \mathrm{ZnSO}_{4} \cdot 7 \mathrm{H}_{2} \mathrm{O} \quad 1.0$, $\mathrm{CuSO}_{4} \cdot 5 \mathrm{H}_{2} \mathrm{O} 1.0$ and $\mathrm{CoCl}_{2} \cdot 2 \mathrm{H}_{2} \mathrm{O} \quad 1.0(2 \mathrm{ml}), \mathrm{CaCO}_{3}$ $0.3 \%$ and agar $0.1 \%$, pH 6.0 ) in a $1000-\mathrm{ml}$ Roux-type flask. The fermentation was carried out at $27^{\circ} \mathrm{C}$ under the static condition. CETP inhibitory activity was observed at day 11 after inoculation and reached a maximun at day 14 .

\section{Isolation and Identification}

The 14-day old whole broth of Fusarium sp. FO-6651 $(800 \mathrm{ml})$ was treated with acetone $(800 \mathrm{ml})$. After centrifugation of the mixture, the supernatant was concentrated and extracted with ethyl acetate $(300 \mathrm{ml}$, twice). The organic layer was dried over $\mathrm{Na}_{2} \mathrm{SO}_{4}$ and concentrated in vacuo to dryness to give a red powder (428 $\mathrm{mg}, \mathrm{IC}_{50} 14.6 \mu \mathrm{g} / \mathrm{ml}$ ). The powder suspended in $30 \%$ $\mathrm{CH}_{3} \mathrm{CN}$ was subjected to an ODS column (Senshu SSCODS-7515-12, $21 \mathrm{ml})$. The materials were eluted by a linear gradient from $30 \% \mathrm{CH}_{3} \mathrm{CN}(100 \mathrm{ml})$ to $100 \% \mathrm{CH}_{3} \mathrm{CN}$ $(120 \mathrm{ml})$ and each $4.8 \mathrm{ml}$ of the elution was collected. The fractions (11th to 23rd) were concentrated and extracted with ethyl acetate to give a brown powder $\left(287 \mathrm{mg}, \mathrm{IC}_{50}\right.$ $12.7 \mu \mathrm{g} / \mathrm{ml}$ ). The powder was purified by HPLC (YMCpack D-ODS-5, $20 \times 250 \mathrm{~mm}$; a linear gradient from $60 \%$ $\mathrm{CH}_{3} \mathrm{CN}$ in $50 \mathrm{mM} \mathrm{NaCl}$ to $75 \% \mathrm{CH}_{3} \mathrm{CN}$ in $50 \mathrm{~mm} \mathrm{NaCl}$ for 60 minutes; UV at $220 \mathrm{~nm} ; 6.0 \mathrm{ml} /$ minute). Four active fractions 1 to 4 , eluted as peaks with retention times of $48.7,65.8,43.5$ and 45.5 minutes were concentrated and 
Table 1. Isolation of L681,512-1, 2, 3 and 4 from ethyl acetate extracts of the culture broth of Fusarium sp. FO-6651.

\begin{tabular}{|c|c|c|c|c|}
\hline Step & $\begin{array}{l}\text { Weight } \\
\text { (mg) }\end{array}$ & $\begin{array}{l}\text { Activity } \\
\left(\mathrm{IC}_{50}: \mu \mathrm{g} / \mathrm{ml}\right)\end{array}$ & $\begin{array}{l}\text { Total activity } \\
\text { (Weight/Activity) }\end{array}$ & $\begin{array}{l}\text { Yield } \\
(\%)\end{array}$ \\
\hline EtOAc ectracts & 428 & 14.6 & 29.3 & 100 \\
\hline ODS column & 287 & 12.7 & 22.6 & 77 \\
\hline HPLC & & & 18.0 & 61 \\
\hline L681,512-1 & 133 & 8.2 & 16.2 & (54) \\
\hline L681,512-2 & 14.1 & 8.7 & 1.62 & $(4.5)$ \\
\hline L681,512-3 & 2.75 & 33 & 0.08 & $(0.3)$ \\
\hline L681,512-4 & 4.34 & 34 & 0.13 & $(0.4)$ \\
\hline
\end{tabular}

Fig. 1. Structures of L681,512-1 to -4 .

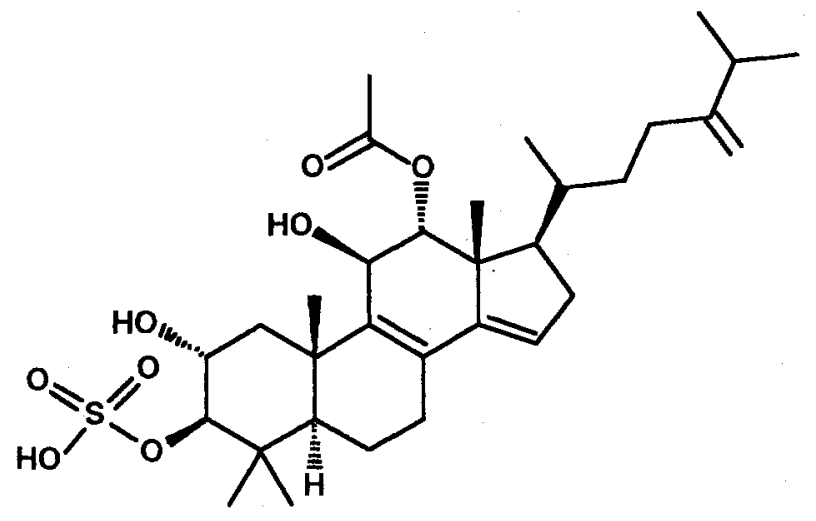

L681,512-1

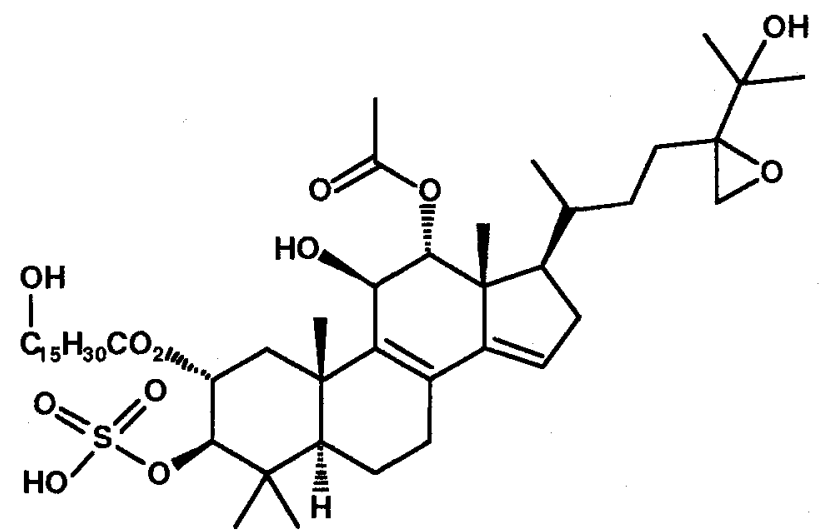

L681,512-3<smiles>C=C(CCC(C)[C@H]1CCC2C3=C([C@H](O)[C@@H](OC(C)=O)[C@@]21C)[C@@]1(C)C[C@H](O)[C@H](OS(=O)(=O)O)C(C)(C)[C@@]1(C)CC3)C(C)C</smiles>

L681,512-2

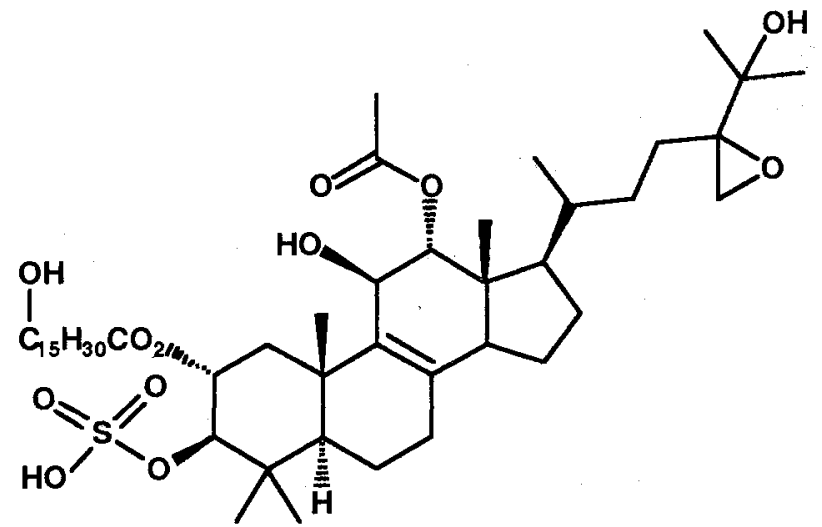

L681,512-4 
Fig. 2. CETP inhibition by $\mathbf{L} 681,512$.

O L681,512-1; L L681,512-2;

$\square \mathrm{L} 681,512-3$; $\mathrm{L} 681,512-4$.

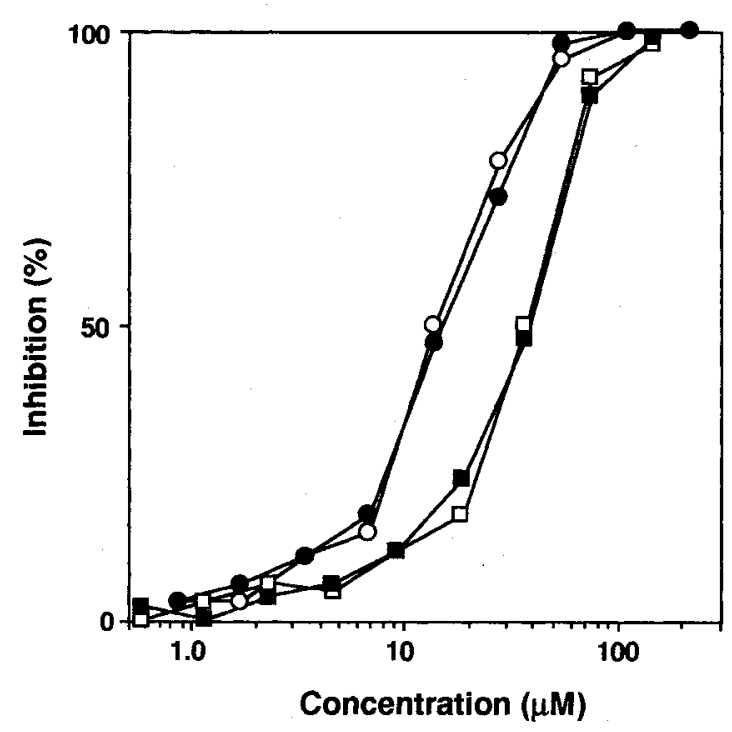

extracted with ethyl acetate to give FO-6651-1 (133 mg, $\left.\mathrm{IC}_{50} 8.2 \mu \mathrm{g} / \mathrm{ml}\right),-2\left(14.1 \mathrm{mg}, \mathrm{IC}_{50} 8.7 \mu \mathrm{g} / \mathrm{ml}\right),-3(2.75 \mathrm{mg}$, $\left.\mathrm{IC}_{50} 33 \mu \mathrm{g} / \mathrm{ml}\right)$ and $-4\left(4.34 \mathrm{mg}, \mathrm{IC}_{50} 34 \mu \mathrm{g} / \mathrm{ml}\right)$ as white powders, respectively. The summary of purification from ethyl acetate extracts of the culture broth is shown in Table 1. From various spectroscopic analyses including NMR, FO-6651-1 to -4 were identified with L681,512-1 to 4 (Fig. 1) previously reported as elastase inhibitors ${ }^{8,9)}$.

Inhibition of CETP Activity by L681,512

The assay for CETP activity was carried out according to our established method ${ }^{3)}$. As shown in Fig. 2, L681,512-1 to -4 inhibited CETP activity in a dose-dependent manner. Furthermore, L681,512-1 ( $\left.\mathrm{IC}_{50}, 13.8 \mu \mathrm{M}\right)$ and $-2(14.6 \mu \mathrm{M})$ were more potent than L681,512-3 $(37.5 \mu \mathrm{M})$ and -4 $(38.5 \mu \mathrm{M})$, indicating that the long acyl side chain in L681,512-3 and -4 is not important for CETP inhibition. When the CETP assay was carried out in the presence of $200 \mu \mathrm{M}$ BSA, a level of albumin similar to that of human plasma $^{4)}$, L681,512-1 and -2 gave $\mathrm{IC}_{50}$ values of 25.3 and $21.8 \mu \mathrm{M}$, indicating that the CETP inhibition by the compounds is partially affected by the presence of BSA in the assay. L681,512-1 to -4 were reported as elastase inhibitors with similar $\mathrm{IC}_{50}$ values $(2.4,2.5,1.9$ and $1.6 \mu \mathrm{M}$, respectively) ${ }^{8)}$. Although these might be no relationship
Table 2. Effect of preincubation of CETP with L681,512-1 on its activity.

\begin{tabular}{|c|c|c|c|}
\hline \multicolumn{2}{|c|}{ L681,512-1 $(\mu \mathrm{M})$} & \multirow{2}{*}{\multicolumn{2}{|c|}{$\begin{array}{l}\text { CETP activity } \\
(\text { dpm) (inhibiton \%) }\end{array}$}} \\
\hline Preincubation & Final & & \\
\hline 0 & 0 & 3779 & (0) \\
\hline 16.8 & 0.60 & 3742 & $(0.3)$ \\
\hline 33.7 & 1.12 & 3667 & (3.0) \\
\hline 67.3 & 2.24 & 3517 & $(7.0)$ \\
\hline 135 & 4.48 & 2956 & (22) \\
\hline 269 & 8.98 & 2095 & (45) \\
\hline
\end{tabular}

Fig. 3. Ex vivo efficacy of L681,512-1 in transgenic mice expressing human CETP and apo A-I.

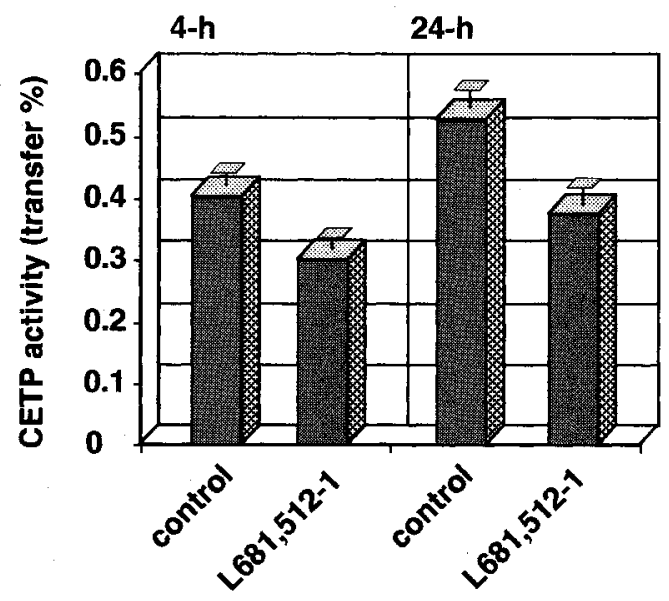

between CETP inhibition and elastase inhibition caused by these compounds, further analyses are necessary to define this point.

\section{Reversible CETP Inhibition by L681,512}

CETP was preincubated with L681,512-1 $(0 \sim 269 \mu \mathrm{M})$ at $37^{\circ} \mathrm{C}$ for 30 minutes, and then a part of the preincubated CETP was transferred into the assay solution to start the reaction. By this method, the inhibitor was diluted about 30 times by the assay solution. As shown in Table 2, the inhibition (\%) of CETP activity at the final drug concentrations, but not at the preincubation concentrations, was almost comparable to the result of Fig. 2, suggesting that 
L681,512-1 inhibits CETP reversibly.

\section{Ex Vivo Inhibition of CETP by L681,512}

Transgenic mice expressing human CETP and human apo $\mathrm{A}-\mathrm{I}^{10)}$ were obtained from Jackson Labs, USA. L681,512-1 dissolved in Cremophor EL solution ( $4 \mu 1$, final $10 \mathrm{mg} / \mathrm{kg}$ ) was administered to the male mice $(n=4$, fasted overnight). Blood was taken at 4 and 24 hours after dosing, and was centrifuged immediately to obtain plasma. The plasma $(25 \mu \mathrm{l})$ was used as a CETP source to determine the CETP activity ${ }^{10}$. As shown in Fig 3 , the activity was inhibited $26 \%$ at 4 hours after dosing, and inhibition was $29 \%$ even at 24 hours. The ex vivo efficacy under the conditions suggests bioavailable inhibition of CETP by the drug.

\section{Acknowledgments}

This research was supported in part by Grant-in-Aid for Scientific Research (B) from the Ministry of Education, Science, Sports and Culture of Japan (09480147), and from Japan Keirin Association.

\section{References}

1) KolzumI, J.; H. Mabuchi, A. Yoshimura, I. Michishita, M. TAKeda, H. Itoh, Y. Sakai, T. Sakai, K. Ueda \& R. TAKEDA: Deficiency of serum cholesteryl-ester transfer activity in patients with familial hyperalphalipoproteinaemia. Atherosclerosis 58: 175 186, 1985
2) Marotti, K. R.; C. K. Castle, T. P. Boyle, A. H. Lin, R. W. Murray \& G. W. Melchior: Severe atherosclerosis in transgenic mice expressing simian cholesteryl ester transfer protein. Nature 364: 73 75, 1993

3) Tomoda, H.; C. Matsushima, N. Tabata, I. Namatame, H. TanaKa, M. J. Bamberger, H. Arai, M. Fukazawa, K. INOUE \& S. ŌMURA: Structure-specific inhibition of cholesteryl ester transfer protein by azaphilones. J. Antibiotics 52: 160 170, 1999

4) Tomoda, H.; N. Tabata, R. Masuma, S. Shu-Yi, \& S. OMURA: Erabulenoles A and B, inhibitors of cholesteryl ester transfer protein, produced by Penicillium sp. FO5637. I. Production, isolation and biological properties. J. Antibiotics 51: 618 623, 1998

5) TABATA, N.; H. TOMODA \& S. ŌMURA: Erabulenols A and B, inhibitors of cholesteryl ester transfer protein, produced by Penicillium sp. FO-5637. II. Structure elucidation of erabulenols $\mathrm{A}$ and B. J. Antibiotics 51: $624 \sim 628,1998$

6) Tomoda, H.; N. Tabata, M. SHINose, Y. TaKahashi, H. B. WOODRUFF \& S. ŌMURA: Ferroverdins, Inhibitors of cholesteryl ester transfer protein produced by Streptomyces sp. WK-5344. I. Production, isolation and biological properties. J. Antibiotics, in press

7) TABATA, N.; H. TOMODA \& S. ÖMURA: Ferroverdins, inhibitors of cholesteryl ester transfer protein produced by Streptomyces sp. WK-5344 II. Structure elucidation of ferroverdins B and C. J. Antibiotics, in press

8) RichaRD, W. B. \& L.D. YUJIN: Anti-inflammatory and antidegenerative compounds isolated from L-681,512. J. P. 1-221391, September 4, 1989

9) Ashe, B. M. \& D. S. Fletcher: Anti-inflammatory and antidegenerative compounds isolated from L-681,512. US 4,874,755, October 17, 1989

10) Breslow, J. L.: Transgenic mouse models of lipoprotein metabolism and atherosclerosis. Proc. Natl. Acad. Sci. USA 90: 8314 8318, 1993 